\title{
Pengaruh Pengelolaan Alokasi Dana Desa Terhadap Kesejahteraan Masyarakat: Studi Kasus Pada Kampung Sumber Boga Distrik Masni Kabupaten Manokwari
}

\author{
Mus Mualim ${ }^{1}$, Marcus R. Maspaitella ${ }^{2}$ \\ ${ }^{1,2}$ Dosen Jurusan Ekonomi Pembangunan, Universitas Papua
}

\begin{abstract}
Abstrak
Konsep pembangunan di Indonesia merupakan upaya peningkatan pemerataan pembangunan beserta hasilhasilnya melalui kebijakan sektoral dan kinerja masyarakat terutama diperdesaan. Untuk mensejahterakan masyarakat kampung, pemerintah mengeluarkan anggaran khusus untuk desa melalui Alokasi Dana Desa (ADD) guna meningkatkan kemandirian masyarakat, termasuk Kampung Sumber Boga. Besarnya ADD untuk Kampung Sumber Boga secara alami harusnya diikuti dengan terjadinya peningkatan kesejahteraan masyarakatnya. Penelitian ini bertujuan untuk menganalisis pengaruh pengelolaan ADD terhadap kesejahteraan masyarakat di Kampung Sumber Boga Distrik Masni Kabupaten Manokwari. Jenis penelitian yang digunakan adalah penelitian kualitatif dan deskriptif dengan menggunakan 88 kepala keluarga sebagai responden yang diperoleh menggunakan teknik purposive sampling. Analisis regresi dilakukan untuk membuktikan kebenaran hipotesis penelittian untuk area Kabupaten Manokwari. Hasilnya menunjukkan bahwa baik secara parsial maupun simultan, seluruh variabel independen mempengaruhi kesejahteraan masyarakat.
\end{abstract}

Kata kunci: alokasi dana desa, kesejahteraan, kebijakan sectoral, pengelolaan

\begin{abstract}
The concept of development in Indonesia is an effort to increase equitable distribution of development and its results through sectoral policies and community performance, especially in rural areas. To prosper the village community, the government issued a special budget for villages through the Village Fund Allocation (VFA) to increase community independence, including the Sumber Boga Village. The amount of VFA for Sumber Boga Village naturally should be followed by an increase in the welfare of the community. This study aims to analyze the effect of the management of VFA on the welfare of the community in Sumber Boga Village, Masni District, Manokwari Regency. The type of research used is qualitative and descriptive research using 88 heads of families as respondents obtained using purposive sampling technique. Regression analysis was carried out and the results show that either partially or simultaneously, all independent variables affect people's welfare.
\end{abstract}

Keywords: village fund allocation, prosperity, sectoral policy, management

How to Cite: Mualim, Mus \& Maspaitella, Marcus R. (2021). Pengaruh Pengelolaan Alokasi Dana Desa Terhadap Kesejahteraan Masyarakat: Studi Kasus Pada Kampung Sumber Boga Distrik Masni Kabupaten Manokwari. JFRES: Journal of Fiscal and Regional Economy Studies, 4(1), 1 - 7 


\section{PENDAHULUAN}

Konsep pembangunan di Indonesia merupakan upaya peningkatan pemerataan pembangunan beserta hasil-hasilnya melalui kebijakan sektoral dan kinerja masyarakat terutama diperdesaan. Pendekatan pembangunan yang menekankan pertumbuhan ekonomi telah mengabaikan jurang yang muncul antara kawasan kota dan desa. Pada saat pembangunan kawasan perkotaan yang dilaksanakan secara terencana dan terpadu, namun di pihak lain pembangunan kawasan desa atau kampung sering kali diserahkan kepada masyarakat itu sendiri untuk mengusahakannya (Tamam, 2004).

Pendekatan pembangunan desa dalam pembangunan masyarakat dilakukan berdasarkan atas fakta ketertinggalan masyarakat desa. Pembangunan lebih seimbang diharapkan akan mampu untuk meningkatkan kualitas hidup masyarakaat desa, terutama aspek sosial dan ekonomi. Pembangunan kawasan desa dan pertanian juga sama penting dari segi proses pembangunan negara secara keseluruhan. Bukan karena wujud kesadaran bahwa kawasan ini 'ketinggalan' berbanding kota saja, namun juga karena kawasan pedesaan mempunyai nilai ekonomi, politik dan sosial. Strategi pembangunan desa meletakkan pembangunan manusiacemerlang dengan menekankan kepada nilai-nilai sosial yang diamalkan oleh masyarakat desa.

Desa merupakan sebuah komunitas kecil yang terikat pada lokalitas tertentu baik sebagai tempat tinggal dan juga tempat pemenuhan kebutuhan hidup masyarakat desa yang bergantung kepada pertanian (Rahardjo, 2010). Pengertian dari masyarakat itu merupakan sekelompok manusia yang saling berinteraksi sehingga dalam masyarakat tersebut akan terdapat kesepakatan-kesepakatan yang telah ditentukan agar ditaati dan dilaksanakan oleh setiap anggota masyarakat. Kesepakatankesepakatan yang sudah ada dalam masyarakat kemudian menjadi pedoman pada setiap warganya, sehingga dapat membedakan antara masyarakat yang satu dengan yang lain (Soekanto, 2006).

Alokasi Dana Desa (ADD) merupakan bagian anggaran keuangan desa yang diperoleh dari bagi hasil pajak daerah dan bagian dari dana perimbangan keuangan pusat dan daerah yang diterima oleh kabupaten/kota untuk desa yang dibagikan secara proporsional. Sesuai dengan
Peraturan Menteri Dalam Negeri No. 37 Tahun 2007 Tentang Pedoman Pengelolaan Keuangan Desa dalam Pasal 18 yang menyatakan bahwa, 'Alokasi Dana Desa berasal dari APBD Kabupaten/Kota yang bersumber dari Dana Perimbangan Keuangan Pusat dan Daerah yang diterima oleh Kabupaten/Kota untuk desa paling sedikit $10 \%$. Kondisi ini memungkinan masyarakat secara optimal dapat membangun desa dengan tetap mempertahankan normanorma sosial yang menjadi bagian tak terpisahkan dari kehidupannya.

Undang-Undang No. 6 Tahun 2014 Tentang Desa beserta Peraturan Pemerintah (PP) Nomor 66 Tahun 2014 tentang Dana Desa yang Bersumber Dari APBN memberikan ketentuan bagi dialokasikannya Dana Desa. Jumlah dana yang ditransfer ke daerah bervariasi antara $\mathrm{Rp}$ 800 juta hingga Rp 1,2 Miliar, tergantung dari beberapa indikator seperti luas wilayah dan jumlah penduduk.

Berdasarkan Peraturan Pemerintah Nomor 72 Tahun 2005 tentang Desa pasal 68 ayat 1 poin c, menyebutkan bahwa bagian dari dana perimbangan pusat dan daerah yang diterima oleh kabupaten/kota untuk desa, paling sedikit $10 \%$ secara proposional pembagiannya untuk setiap desa, dana ini dalam bentuk Alokasi dana Desa atau sering disebut sebagai ADD. Alokasi Dana Desa (ADD) merupakan dana yang dialokasikan oleh Pemerintah Kabupaten untuk desa, yang bersumber dari bagian dana perimbangan keuangan pusat dan daerah yang diterima oleh Kabupaten. Alokasi Dana Desa merupakan dana yang cukup signifikan bagi Desa untuk menunjang program-program Desa. Pengelolaan keuangan baik dari anggaran sampai realisasi harus melibatkan tokoh-tokoh masyarakat dan aparat Pemerintah Daerah. Kendala-kendala yang dihadapi oleh Pemerintah Daerah baik Pemerintah desa dan Pemerintah Kecamatan adalah kurangnya pengendalian terhadap pengelolaan dana yang berasal dari Alokasi Dana Desa.

Kampung Sumber Boga, di Distrik Masni Kabupaten Manokwari merupakan salah satu kampung yang ikut serta menunjang pertumbuhan ekonomi daerah. Walaupun sumbangsih terhadap perekonomian terbilang kecil, namun sebagai entitas Pertumbuhan ekonomi tidak luput dari jumlah penduduk berdasarkan mata pencaharian masyarakat pada kampung tersebut, jumlah penduduk berdasarkan 
mata pencaharian di kampung Sumber Boga dapat dilihat pada tabel 1.

Tabel 1. Penduduk Kampung Sumber Boga Menurut Mata Pencaharian Tahun 2017

\begin{tabular}{lrrr}
\hline \multirow{2}{*}{ Mata Pencaharian } & \multicolumn{3}{c}{ Penduduk (jiwa) } \\
\cline { 2 - 5 } & Laki-laki & Perempuan & Jumlah \\
\hline Petani & 809 & 805 & 1.614 \\
\hline Nelayan & 2 & 0 & 2 \\
\hline Pedagang & 106 & 141 & 247 \\
\hline PNS & 35 & 19 & 54 \\
\hline TNI/POLRI & 7 & 0 & 7 \\
\hline Belum/tidak bekerja & 441 & 301 & 742 \\
\hline Tenaga honorer & 5 & 7 & 13 \\
\hline Buruh harian lepas & 10 & 5 & 15 \\
\hline Supir $\quad$ Total & 22 & 0 & 22 \\
\hline \multicolumn{1}{r}{$\quad 1.438$} & 1.278 & 2.716 \\
\hline
\end{tabular}

Sumber: RKP Kampung Sumber Boga, 2017

Mata pencaharian penduduk Kampung Sumber Boga sebagian besar adalah petani. Hal ini berjalan turun-temurun sejak kampung ini dibuka. Meskipun demikian, ada beberapa penduduk yang bekerja sebagai pedagang, nelayan, PNS, dan TNI/POLRI. Sedangkan yang tidak atau belum bekerja merupakan ibu-ibu rumah tangga dan anak-anak yang masih berada di bangku sekolah atau sedang dalam pendidikan. Untuk mensejahterakan masyarakat kampung pemerintah mengeluarkan anggaran khusus untuk desa yaitu Alokasi Dana Desa(ADD) guna meningkatkan kemandirian masyarakat Kampung Sumber Boga,pengalokasian ADD Kampung Sumber Boga dapat dilihat pada tabel dibawah ini.

Tabel 2. Dana Desa Kampung Sumber Boga Tahun 2017

\begin{tabular}{|c|c|c|c|c|c|}
\hline \multirow{2}{*}{ No } & \multirow{2}{*}{ Bidang/Kegiatan } & \multicolumn{4}{|c|}{ Sumber Pembiayaan (Ribu Rupiah) } \\
\hline & & APBN & ADD & Otsus & Jumlah \\
\hline 1 & $\begin{array}{l}\text { Bidang Penyelenggaraan } \\
\text { Pemerintahan Kampung }\end{array}$ & - & 184.500 & - & 184.500 \\
\hline 2 & $\begin{array}{l}\text { Bidang Pelaksanaan Pembangunan } \\
\text { Kampung }\end{array}$ & $746.430,900$ & - & - & $756.430,900$ \\
\hline 3 & Bidang Pembinaan kemasyarakatan & $129.450,000$ & - & - & $129.450,000$ \\
\hline 4 & Bidang Pemberdayaan Masyarakat & $59.830,075$ & - & 100.000 & $159.830,075$ \\
\hline & Jumlah & $935.710,975$ & 184.500 & 100.000 & $1.220 .210,975$ \\
\hline
\end{tabular}

Sumber: RKP Kampung Sumber Boga, 2017

Dalam rangka pemberdayaan masyarakat kampung guna meningkatkan kemandirian sesuai hasil Musrenbang Kampung tahun 2016 dan rekomendasi Pendamping Distrik mengenai rencana tahun anggaran 2017, maka kegiatan pembangunan kampung tahun 2017 direncanakan sebesar Rp 1.220.210.975,-Sasaran penggunaan anggaran yang disusun sesuai dengan arahan Permendagri No 113 Tahun 2014, rincian untuk masing-masing kegiatan yang tertuang dalam daftar usulan RKP-Kampung Sumber Boga.Bahwa kegiatan tersebut dikelola oleh pemerintah kampung secara terbuka tertib dan lancar serta dapat dipertanggungjawabkan, oleh karena itu ditetapkan susunan tim pelaksanaan kegiatan.
Besarnya ADD untuk Kampung Sumber Boga secara alami harusnya diikuti dengan terjadinya peningkatan kesejahteraan masyarakatnya. Karena tujuan akhir dialokasikannya dana desa adalah peningkatan kesejahteraan warga desa. Undang-Undang Desa yang menitikberatkan pembangunan dimulai dari desa ke kota memiliki tujuan pokok yakni peningkatan kesejahteraan warga desa. Maka jika besarnya ADD yang telah dikucurkan pemerintah ternyata tidak berbanding lurus dengan perbaikan kehidupan ekonomi warga desa, memberikan pesan nyata bahwa ada masalah dalam pengelolaan ADD di kampung.

Pada tahun 2005 pemerintah mengeluarkan kebijakan Alokasi Dana Desa (ADD), yang ditandai dengan terbitnya Peraturan Pemerintah 
Nomor 72 Tahun 2005, yang menyebutkan bahwa desa adalah kesatuan masyarakat hukum yang memiliki batas-batas wilayah yang berwenang untuk mengatur kepentingan masyarakat setempat, berdasarkan asalusul dan adat istiadat setempat yang diakui dan dihormati dalam sistem Pemerintahan Negara Kesatuan Republik Indonesia. Dan pemerintahan desa berdasarkan PP No. 72 Tahun 2005 adalah penyelenggaraan urusan pemerintahan oleh Pemerintahan Desa dan Badan Permusyawaratan Desa dalam mengatur dan mengurus kepentingan masyarakat setempat berdasarkan asalusul dan adat-istiadat setempat yang diakui dan dihormati dalam sistem Pemerintahan Negara Kesatuan Republik Indonesia (Saputra, 2016).

Menurut Rozaki dkk (2005) sesungguhnya kebijakan alokasi dana desa yang telah dijalankan memiliki tujuan besar yang kurang lebih sama yaitu merombak ortodoksi pemerintah kabupaten dalam memberikan kewenangan, pelayanan dan bantuan keuangan kepada pemerintahan di level bawahnya (desa). Pola kebijakan pemerintahan kabupaten yang semula dominan dan sentralis, melalui metode alokasi dana desa ini berubah menjadi partisipatif, responsif, dan dijalankan melalui asas desentralisasi.

Alokasi dana desa merupakan bagian dari keuangan desa yang diperoleh dari bagi hasil pajak daerah dan bagian dari dana perimbangan keuangan pusat dan daerah yang diterima oleh kabupaten untuk desa paling sedikit $10 \%$ (sepuluh persen). Seluruh kegiatan yang berasal dari anggaran alokasi dana desa direncanakan, dilaksanakan, dan dievaluasi secara terbuka dengan melibatkan seluruh masyarakat desa.

Menurut Arikunto (2007) pengelolaan dapat disamakan dengan kata manajemen, yang berarti penaturan atau pengurusan. Pengelolaan adalah pengendalian dan pemanfaatan semua sumber daya yang menurut suatu perencanaan atau penyelesaian suatu tujuan kerja tersebut.

Pengelolaan dana desa adalah bagian yang tidak terpisahkan dari pengelolaan keuangan desa dalam APBDesa.Karena itu dalam pengelolaan keuangan dana desa harus memenuhi prinsip pengelolaan alokasi dana dalam (Lapananda, 2016) sebagai berikut:
1. Dana desa dilaksanakan dengan menggunakan prinsip hemat, terarah dan terkendali.

2. Seluruh kegiatan harus dapat dipertanggungjawabkan secara teknis hukum.

3. Seluruh kegiatan yang di danai oleh dana desa direncanakan, dilaksanakan dan dievaluasi secara terbuka dengan prinsip dari, oleh dan untuk rakyat.

Tingkat kesejahteraan adalah konsep yang digunakan untuk menyatakan kualitas hidup suatu masyarakat atau individu suatu wilayah pada sutu waktu yang tertentu. Konsep kesejahteraan yang dimilili bersifat relatif. Sejahtera bagi seseorang dengan tingkat pendapatan tertentu belum dapat juga dikatakan sejahtera bagi orang lain (Zakaria, dkk., 2014). Menurut Mosher (1987) mengatakan bahwa kesejahteraan petani dijelaskan dari beberapa aspek kesejahteraan rumah tangga yang tergantung pada tingkat pendapatan petani.

Alokasi dana desa merupakan salah satu sumber keuangan desa yang diterima dari berbagai hasil dana perimbangan setelah dikurangi dana alokasi khusus minimal $10 \%$ akan digunakan pemerintah desa dalam melaksanakan pemerintahannya. Adapun faktor-faktor penentu pengelolaan dana desa antara lain:

\section{a. Partisipasi masyarakat}

Partisipasi masyarakat merupakan keterlibatan seseorang atau suatu kelompok (masyarakat) secara aktif dalam berkontribusi dengan suka rela pada sebuah program pembangunan, seperti terlibat dalam hal perencanaan,pelaksanaan, monitoring sampai juga ke evaluasi.Partisipasi masyarakat dapat dilihat dari keinginan masyarakat dalam mengibahkan sebagian tanahnya kepada pemerintah desa.

Hutami (2017) mengatakan bahwa faktor penunjang terlaksananya realisasi pengunaan ADD masyarakat cukup merespon dan dalam pembuatan jalan tani masyarakat mengibahkan sebagian tanahnya.

\section{b. Sarana dan prasarana}

Sarana adalah sesuatu yang dapat dipakai sebagai alat dalam mencapai maksud dan tujuan. Sedangkan prasarana adalah sesuatu yang merupakan penunjang utama terselenggaranya suatu proses (usaha,proyek dan pembangunan). Tujuan diadakan perencanaan sarana dan 
prasarana yaitu untuk menghadiri terjadinya kesalahan dan kegagalan yang tidak diinginkan dan untuk meningkatkan efektivitas dan efesiensi dalam pelaksanaannya.

Berdasarkan uraian di atas, maka penulis memandang penting untuk dilakukan sebuah penelitian yang fokus pada pengelolaan ADD untuk meningkatkan kesejahteraan masyarakat kampung. Oleh karenanya, penulis mengajukan sebuah penelitian dengan judul “ Pengaruh Pengelolaan Alokasi Dana Desa Terhadap Kesejahteraan Masyarakat (Studi Pada Kampung Sumber Boga Distrik Masni Kabupaten Manokwari)".

\section{METODE PENELITIAN}

Lokasi penelitian ini dilaksanakan di Kampung Sumber Boga distrik Masni Kabupaten Manokwari. Jenis penelitian yang digunakan dalam penelitian ini adalah penelitian kualitatif dan deskriptif. Objek dalam penelitian ini adalah Alokasi Dana Desa (ADD) di Kampung Sumber Boga Distrik Masni Kabupaten Manokwari tahun anggaran 2016-2018.

Jenis data yang digunakan dalam penelitian ini adalah data sekunder dan data primer. Data yang digunakan dalam penelitian ini diperoleh dengan teknik observasi dan wawancara. Dalam penelitian ini populasi adalah seluruh masyarakat Kampung Sumber Boga. Jumlah penduduk di Kampung Sumber Boga berjumlah 734 kepala keluarga. Sampel pada penelitian ini adalah sebagian dari jumlah penduduk Kampung Sumber Boga. Metode penarikan sampel pada penelitian ini menggunakan formula Slovin (Umar, 2005) sebagai berikut:

$$
\mathrm{n}=+\frac{\mathrm{N}}{1+\mathrm{n}(\mathrm{e})^{2}}
$$

Dimana:

$\mathrm{n}$ : ukuran sampel

$\mathrm{N}$ : jumlah populasi

e : kesalahan dalam pengambilan sampel

Menggunakan formula Slovin di atas maka, jumlah sampel dalam penelitian ini adalah:

$$
\mathrm{n}=\frac{734}{1+734(0.1)^{2}}=\frac{734}{1+7.34}=88
$$

Berdasarkan perhitungan, maka diperoleh sampel sebanyak 88 Kepala Keluarga atau responden. Jadi sampel dalam penelitian adalah 88 responden $(n=88)$. Pengambilan sampel pada penelitian ini menggunakan teknik purposivesampling.

Regresi linier berganda digunakan oleh peneliti untuk mengukur kekuatan hubungan antara dua variabel atau lebih, juga menunjukkan arah hubungan antara variebel dependen dengan variabel independen. Bentuk persamaan dari regresi linier berganda penelitian ini sebagai berikut:

$Y=\alpha+\beta_{1} X_{1}+\beta_{2} X_{2}+\beta_{3} X_{3}+\beta_{4} X_{4}+\epsilon$

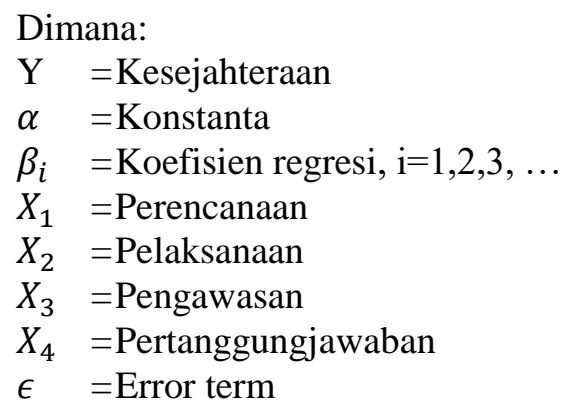

\section{HASIL PENELITIAN}

Kampung Sumber Boga merupakan Kampung eks transmigrasi yang berasal dari luar pulau Papua. Dahulu Kampung Sumber Boga disebut Kampung Prafi B Unit II SP7 dan masuk dalam wilayah administratif kelurahan Amban, Kecamatan Manokwari hingga pada tahun 1988 terjadi pemekaran desa yang mengakibatkan lahirnya wilayah administratif yang bersifat definitif dengan nama desa Sumber Boga. Sumber Boga terdiri dari dua kata, yakni sumber dan boga, sumber artinya tempat asal sedangkan boga artinya adalah pangan (makanan) atau sarana untuk hidup. Jadi dari pemahaman sederhana itu, dapat ditarik kesimpulan bahwa sumber boga merupakan tempat atau sarana yang dapat mendatangkan kesejahteraan bagi warga masyarakat di kampung maupun di kabupaten manokwari.

Jumlah penduduk kampung Sumber Boga tahun 2016 tercatat sebanyak 2.690 jiwa dengan jumlah rumah tangga sebanyak 1.210 KK. Dan dari jumlah KK tersebut terdapat Rumah Tangga Miskin sebanyak 136 KK. Jumlah penduduk Kampung Sumber Boga secara umum adalah 2.690 jiwa. Jumlah penduduk laki laki berjumlah sekitar 1424 jiwa, sedangkan jumlah penduduk perempuan berjumlah sekitar 1.266 jiwa. Total semua penduduk masyarakat kampung sumber boga berjumlah 2.690 jiwa. 
Mata pencaharian penduduk Kampung Sumber Boga sebagaian besar adalah petani. Hal ini telah berjalan turun-temurun sejak pertama kampung ini dibuka. Meskipun demikian, ada beberapat penduduk yang bekerja sebagai pedang, peternak, PNS dan TNI/ POLRI.

Dalam pengembangan potensi yang ada baik itu potensi alam maupun potensi sumber daya manusia, masyarakat kampung Sumber Boga juga tidak terleppas dari permasalahan permasalahan. Permasalahan ini muncul dikarenakan tingkat pendidikan masyarakkat yang masih sangat rendah sehingga potensi yang ada belum termanfaatkan secara optimal. Permasalah utama yang dihadapi masyarakat kampung Sumber Boga adalah belum adanya fasillitas sarana dan pra sarana yang memadai untuk peningkatan sumber daya pemanfaatan masyarakat dan fasilitas pelayanan umum guna menunjang pengembangan perekonomian yang bertumpu pada ekonomi masyarakat.

Hasil regresi linear berganda menunjukkan bahwa seluruh variabel independen baik X1, X2, $\mathrm{X} 3$ dan $\mathrm{X} 4$ berpengaruh terhadap variabel dependen (Y). Hasil regresi linear berganda selanjutnya dimasukkan ke dalam formula model penelitian sebagai berikut:

$$
\begin{aligned}
Y_{\text {Kesejahteraan }}= & 2,675+0,1_{\text {Perencanaan }}+ \\
& 0,272_{\text {Pelaksanaan }}+0,369_{\text {Pengawasan }}+ \\
& 0,683_{\text {Pertanggungawawan }}
\end{aligned}
$$

Berdasarkan formula hasil regresi linear berganda di atas, maka dapat diinterpretasikan sebagai berikut:

a. Variabel Perencanaan (X1) berpengaruh positif dan signifikan sebesar 0,1 yang mempunya makna bahwa setiap peningkatan kualitas perencanaan pengelolaan ADD sebesar 1\%, maka akan meningkatkan kesejahteraan masyarakat sebesar $0,1 \%$.

b. Variabel Pelaksanaan (X2) berpengaruh positif dan signifikan sebesar 0,272 yang mempunya makna bahwa setiap peningkatan kualitas pelaksanaan pengelolaan ADD sebesar $1 \%$, maka akan meningkatkan kesejahteraan masyarakat sebesar $0,272 \%$.

c. Variabel Pengawasan (X3) berpengaruh positif dan signifikan sebesar 0,369 yang mempunya makna bahwa setiap peningkatan kualitas pengawasan pengelolaan ADD sebesar 1\%, maka akan meningkatkan kesejahteraan masyarakat sebesar $0,369 \%$.

d. Variabel pertanggungjawaban

berpengaruh positif dan signifikan sebesar 0,683 yang mempunya makna bahwa setiap peningkatan kualitas pertanggungjawaban pengelolaan ADD sebesar 1\%, maka akan meningkatkan kesejahteraan masyarakat sebesar $0,683 \%$.

Selanjutnya hasil penelitian ini sejalan dengan penelitian Diansari (2015) yang menyebutkan bahwa faktor pengawasan menentukan baik tidaknya pengelolaan ADD. Meskipun dalam penelitian ini variabel pengawasan bukan yang paling besar pengaruhnya terhadap kesejahteraan, namun variabel pengawasan berpengaruh positif dan signifikan terhadap pengelolaan ADD di Kampung Sumber Boga. Hasil ini juga sesuai dengan penelitian Putra dkk. (2013) yang juga menekankan pada faktor pengawasan dalam pengelolaan ADD.

Berikutnya, penelitian ini juga sejalan dengan penelitian Arifiyanto dan Kurrohman (2014) yang menekankan pada faktor perencanaan dan pelaksanaan pengelolaan ADD sebagai penentu pengelolaan ADD yang akuntabel. Namun hasil penelitian ini bertentangan dengan hasil penelitian Azwardi dan Sukanto (2014) yang menunjukkan bahwa adanya ADK ikut berkorelasi pada peningkatan kemiskinan di masyarakat. Penelitian ini justru mendapatkan fakta bahwa pengelolaan ADK di Kampung Sumber Boga berdampak positif terhadap kesejahteraan masyarakat.

\section{KESIMPULAN}

Berdasarkan hasil penelitian dan pembahasan mengenai Pengaruh Pengelolaan Alokasi Dana Desa Terhadap Kesejahteraan Masyarakat pada Kampung Sumber Boga Distrik Masni Kabupaten Manokwari Tahun 2016-2018, maka dapat kesimpulan bahwa, alokasi dana desa yang disalurkan dari pusat kepada daerah dan di teruskan kerekening pemerintahan kampung Sumber Boga secara kualitatif realisasi penuh atau terserap $100 \%$. Akan tetapi dari segi pengelolaan dan peran serta masyarakat belum optimal.

Proses penggunaan dana desa dikampung Sumber Boga meliputi proses: kesejahteraan, perencanaan, pelaksanaan, penatausahaan dan pelaporan. Tingkat kesejahteraan berdasarkan 
hasil penelitian dilihat dari kualitas hidup suatu masyarakat atau individu suatu wilayah pada suatu waktu tertentu, konsep kesejahteraan yang dimiliki bersifat relatif.

Tahap perencanaan berdasarkan hasil penelitian dimiliki dari jumlah keseluruhan/rata-rata dari sosialisasi, pengaruh sosialisasi, keterbukaan pemerintah kampung kepada masyarakat, serta saran dan masukan yang sampai kepada pemerintah dengan baik dan efektif. Pelaksanaan berdasarkan hasil penelitian cukup efektif, dimana peran pemerintah dalam tahapan pelaksanaan, pengaruh sosialisasi program ketika sedang dilaksanakan kegiatan, kerjasama yang dilakukan pemerintah kampung dan masyarakat, serta keberhasilan pembangunan fisik di kampung Sumber Boga belum optimal secara keseluruhan.

Pengawasanpengelolaan Alokasi Dana Kampung Desa Sumber Boga dilakukan oleh bendahara kampung dijalankan dengan baik dan sesuai prinsip akuntabilitas pengelolaan ADD. Pertanggung jawaban pengelolaan Alokasi Dana Desa (ADD) di Lampung Sumber Boga Ditrik Masni Kabupaten Manokwari telah berjalan dengan baik. Faktor-faktor yang mempengaruhi pengelolaan alokasi dana desa di Kampung Sumber Boga Distrik Masni Kabupaten Manokwari antara lain Partisipasi Masyarakat, Sarana dan prasarana.

\section{DAFTAR PUSTAKA}

Arifiyanto, D. F., \& Kurrohman, T. 2014. Akuntabilitas pengelolaan alokasi dana desa di Kabupaten Jember. Jurnal Riset Akuntansi dan Keuangan, 2(3).

Arikunto, S. 2007. Prosedur Penelitian Suatu Pendekatan Praktek. Edisi Revisi VI.Jakarta: Rineka Cipta.

Azwardi, A. and Sukanto, S., 2014. Efektifitas Alokasi Dana Desa (ADD) dan Kemiskinan di Provinsi Sumatera Selatan. Jurnal Ekonomi Pembangunan (Journal Of Economics And Development), 12(1), pp.29-41. Badan Pusat Statistik. 2014. Anggaran Pendapatan Negara. Jakarta. Di akses dari www.bps.go.id pada tanggal 10 Februari 2019.

Hutami, A. S. S. (2017). Analisis Pengelolaan Alokasi Dana Desa (ADD) di Desa Abbatireng Kecamatan Gilireng, Kabupaten
Wajo. Government:

Jurnal

Ilmu

Pemerintahan, 10-19.

Putra, Candra K., Pratiwi, Ratih N., Suwondo, 2013 Pengelolaan Alokasi Dana Desa Dalam Pemberdayaan Masyarakat Desa. Jurnal Administrasi Publik, Vol I,No. 6.

Departemen Pendidikan Nasional. (2011). Kamus Besar Bahasa Indonesia (edisi keempat). Jakarta : PT. Gramedia Pustaka Utama.

Umar, Husein, 2005. Metode Penelitian. Jakarta : Salemba Empat.

Lapananda, Y. 2016. Hukum Pengelolaan Keuangan Dana Desa. Jakarta: PT. Wahana Semesta Indonesia.

Mosher, A.T. 1987. Menciptakan Struktur Pedesaan Progresif. Disunting oleh Rochim Wirjoniodjojo. Yasaguna. Jakarta.

Mankiw, N.G. 2011. Principles of Economic, 6th Edition. Mason: South-Western Cengage Learning.

Rahardjo,2010,Pembangunan Pedesaan dan Perkotaan, Graha Ilmu, Yogyakarta.

Rozaki, dkk, 2005, Prakarsa Desentralisasi dan Otonomi Desa, Yogyakarta : Ire Press.

Diansari, Rani Eka. (2015). Analisis Implementasi Alokasi Dana Desa (ADD) Kasus Seluruh Desa di Kecamatan Kledung Kabupaten Temanggung Tahun 2013. Seminar Nasional Universitas PGRI Yogyakarta.

Soekanto. 2006. Sosiologi Suatu Pengantar. Jakarta: Raja Grapindo Persada.

Saputra. 2016. Pengaruh Proses dan Kualitas Pelayanan Terhadap Kepuasan Pelanggan MNC Play Media, Jurnal Manajemen, Volume 12, Nomor 2.

Zakaria, W.A., Endaryanto, T., Indah, L.S.M. and Mutolib, A., 2019. Transformasi Struktur Ekonomi Dan Kesejahteraan Rumah Tangga Petani Ubikayu Di Provinsi Lampung.

Tamam Achda. 2004. Mendahulukan yang Tertinggal. Laporan Studi Penjajakan Kebutuhan Pangan Adopsi Desa Miskin di Jawa Barat. Jakarta: Penerbit Pusat Pemberdayaan Masyarakat (Center for Social Empowerment) Universitas Nasional. 